Hipotenusa : Journal of Mathematical Society

Volume 3 Issue 1 Year 2021

ISSN: $2716-3156$

Website: https://hipotenusa.iainsalatiga.ac.id/index.php/hipotenusa/index

\title{
Analysis of Professional Competence of Mathematics Education Students during the Covid-19 Pandemic
}

\author{
Bambang Priyo Darminto ${ }^{1 *}$, Budy Sugandi ${ }^{2}$ \\ ${ }^{1}$ Universitas Muhammadiyah Purworejo, Indonesia \\ ${ }^{2}$ Southwest University in Chongqing, China \\ *Corresponding Author, email: bambangpdc115@gmail.com \\ DOI: 10.18326/hipotenusa.v3i1.80-96
}

$\begin{array}{ll}\text { Article submitted } & \text { : February 5, 2021 } \\ \text { Article reviewed } & \text { : April 20, 2020 } \\ \text { Article published } & \text { : June 1, 2021 }\end{array}$

\begin{abstract}
The effects of the Covid-19 pandemic have penetrated all aspects of human life, including education. One of the pandemic consequences is that universities require that lectures be carried out online, where may affect student learning outcomes. This study aimed at determining the impact of online lectures during the Covid-19 pandemic on the professional competence of students as mathematics pre-service teacher at the Muhammadiyah University of Purworejo. This was quantitative research. The population were the first semester students in 2020 at the Mathematics Education Department of Muhammadiyah University of Purworejo. The research sample was taken through random cluster sampling, including 30 students from the population. The data were obtained using a professional competency test instrument. The data processing method used one-sample average statistical test by comparing with the professional competency scores of students in 2018. Based on the study results, it was found that there was a significant decrease in the professional competency scores of Mathematics Education students whose lectures were conducted online during the Covid-pandemic 19 compared to the professional competency scores of Mathematics Education students whose lectures were conducted face-to-face.
\end{abstract}

Keywords: professional competence, covid-19, college student, mathematics education

\section{INTRODUCTION}

Teachers are educational pillars of a country to progress and develop. The strategic role of education certainly requires teacher competence in various aspects because it requires expertise, proficiency, or proficiency with a certain quality standard so that it must be done by someone who has been trained. The professionalism of a teacher can serve to improve the quality of national education (Law No. 14 of 2005). 
Becoming a professional teacher, according to Article 7 of Law no. 14 of 2005 on Teachers and Lecturers, needs to be based on nine principles. Five of them include: (1) having a commitment to improving the quality of education, faith, piety, and noble character, (2) having academic qualifications and educational background that are in accordance with the field of work, (3) having the necessary competencies according to with the field of duty, (4) having responsibility for the implementation of professional duties, and (5) having the opportunity to develop professionalism in a sustainable manner by lifelong learning. In addition, it was also explained that teachers are required to have academic qualifications, competencies, teacher certificates, be physically and mentally healthy, and have the ability to realize the goals of national education. Furthermore, it was explained that the teacher's competence includes 4 competencies: professional competence, pedagogical competence, social competence, and personality competence. (Law No. 14 of 2005). All teacher competencies are needed by teachers for activities in the world of education and serve as a guide for teacher behaviour to carry out tasks at school and deal with stakeholders. (Wahyudi, 2010).

Competencies directly related to the field of work of a teacher are called professional competence. It is an ability or skill related to the mastery of the material being taught or the teacher's discipline concerned. This involves various matters, including mastery of subject competency standards, material development, strategies, and the use of information technology. In order to teach well, the professional competence of teachers must also be good. In addition, the professional competence of teachers has a positive influence on student learning outcomes (Darlin, 2020; Daryati, 2016). Therefore, this professional competence is an essential ability for a person to become a reliable teacher.

The Covid-19 pandemic that hit the world in early 2020 has resulted in system changes in various aspects of human life. In Indonesia, the government has adopted a policy of doing work from home (WFH) for workers, including teachers and lecturers, doing social and physical distancing, requiring people to stay at home, work, worship and learn from home. In the world of education, the learning process is carried out online (in a network), including at the university level (Sumargiyani \& Nafi'ah, 2020). Such conditions require educational institutions to carry out various innovations in the learning process, both relating to human resources, teaching methodologies, provision 
of technology and other learning facilities and infrastructure. Therefore, educators and students are expected to be able to adapt to these conditions and must be able to take advantage of technology as the main means of learning online.

In connection with learning or lectures during the Covid-19 pandemic, Muhammadiyah Purworejo University (UMP) also carries out a program from the government, namely implementing online lectures. Some lecturers still conduct lectures in person or face-to-face even though they have to comply with health protocols. In direct lectures, the lecturer determines the number of students who attend is set at a maximum of $50 \%$ per class. In addition, students who take face-to-face lectures are required to wear a mask, and their body temperature is also detected before entering class. If the student is declared unwell, then the student concerned may not attend lectures. This is done so that face-to-face lectures can run well and still comply with health protocols.

As one of the subjects taught since elementary school, mathematics has an important role in human life. In connection with the challenges of learning mathematics in the future, especially in entering the 21 st century, current mathematics courses are directed at increasing professional competence by developing higher-order thinking characteristics, including critical thinking, innovative and problem-solving skills. This is in accordance with mathematics learning in the 21 st century, which has objectives with $4 \mathrm{C}$ characteristics, namely Communication, Collaboration, Critical Thinking and Problem Solving, and Creativity and Innovation. (Arifin, 2017). Besides, critical thinking skills, according to Facione (Karim \& Normaya, 2015) also include interpretation, analysis, evaluation, and inference. Mathematical problem solving is one of the most important things in 4C. According to Hamzah (Wahyuni, 2017), To solve a mathematical problem, students need a higher-order thinking concept, namely the ability to think from the aspect of analyzing to creating. As for critical thinking, Duron et al. (2006) state that "critical thinking is very simply stated, the ability to analyze and evaluate information". Critical thinking is critical to problem-solving efforts (Ambarawati et al., 2014). This critical thinking ability is needed to address the inevitable problems in life to make decisions more precisely. This is because someone who thinks critically will organize, adjust, change, or improve his mind (Maulana, 2017). 
Because of the importance of professional competence for teachers, online lectures during this pandemic are expected not to reduce the professional competence skills of prospective teachers at the Muhammadiyah University of Purworejo. In connection with the description above, the main objective of this study is to determine the impact of online lectures during the Covid-19 pandemic on the professional competence owned by the prospective mathematics teachers at the Muhammadiyah University of Purworejo.

\section{METHOD}

This research was conducted at the Mathematics Education Department of Muhammadiyah University of Purworejo from April to December 2020 using a quantitative approach, with the population were the first semester students. In comparison, the research sample was taken by random cluster sampling as many as 30 from the population. The instrument used in this study was a test in 150 minutes, which included: (1) set theory material (including the set of numbers, absolute value, absolute price equations and inequalities), (2) relations and functions (including inverses, functions). Inverse, function composition, and properties of function composition), (3) mathematical logic (open sentence, conjunction, disjunction, implication, biimplication, exclusive disjunction, tautology, contradiction, and the laws of proportional logic), (4) limit function algebra, trigonometric functions, logarithmic functions, and exponential functions, (5) derivatives of algebraic functions, trigonometry, logarithmic functions, and exponential functions and their applications, and (6) indefinite integrals, certain integrals and their applications (to calculate area, the volume of objects turn, and the length of the curve). The subjects used in making the test were based on the 2015 Muhammadiyah University Mathematics Education Curriculum. Similar tests have also been used to determine or measure the professional competence of the first semester students in 2018. The statistical test of this study is to compare the students average professional competency score before the Covid-19 pandemic in 2018 and those during the outbreak of the Covid-19 pandemic. Therefore, this research tried to compare the average score of students' professional competence during online and offline/ face to face learning. The data on the results of the average assessment of professional competence before the Covid-19 pandemic taken in 2018 was 68.74 (Darminto, 2018). 
Furthermore, the steps from the results of this study are processed through the following stages:

1. Determining the hypothesis and the level of significance (in this study $\alpha=5 \%$ ).

2. Using the one-sample average test with test statistics: $t_{\text {count }}=\frac{\bar{x}-\mu_{0}}{\frac{s}{\sqrt{n}}}$.

3. Determining the critical area $t_{(\alpha, \vartheta)}$.

4. Determining the test decision, $H_{0}$ is rejected, if $t_{\text {count }}<t_{(\alpha, \vartheta)}$

\section{RESULTS AND DISCUSSION}

The Covid-19 pandemic has been epidemic throughout the world and since March 11, 2020 WHO has designated this outbreak as a worldwide pandemic. Since the Covid19 outbreak became a global pandemic, many of these things have been affected and have had an impact on all aspects of human life. This has led several countries to establish policies to impose lockdowns in order to prevent the spread of covid-19. In Indonesia, due to several limitations, the government has imposed a Large-Scale Social Restriction (PSBB) policy. Therefore, all activities carried out outside the home must be stopped until this pandemic subsides, including the world of education where the learning process in schools and lectures on campuses is temporarily replaced by distance learning. With this policy, learning/lectures that were previously conducted in person or face-to-face are replaced with distance learning conducted online or online. At the Muhammadiyah University of Purworejo, this distance learning is carried out by lecturers through online media such as WhatsApp, Google Meet, Google Form, Elijo and other types of online media. In the view of researchers, the change in the lecture process is likely to affect student learning outcomes. Therefore, in order to be successful, all matters related to learning need to be well prepared. Based on Girsang's observations, there are five things that influence the success of the online learning process, namely: (1) smooth internet access; (2) possess information technology facilities/tools (gadgets/computers); (3) online learning application program can be done easily; (4) have internet quota, and (5) have parental assistance (Girsang, 2020). Especially for learning in tertiary institutions, the 5th aspect above does not really affect students because they are considered to have high awareness about learning. This is in accordance with research Zein \& Ariyani (2017), who concluded that there is no relationship between parental guidance and student academic achievement because 
basically children at the college level have more independence. Furthermore, if the four things that affect the success of the online learning process above are not fulfilled properly, the results of online learning during the Covid-19 pandemic may show unsatisfactory results.

This study aimed to determine the professional competence score and analyze student learning outcomes, especially for prospective mathematics teachers, about the effect of online lectures on their professional competence. The results of this study are in the form of numbers from the test results about the introduction of basic mathematics to students who are taken as samples. The rating scale used in this study is the ratio scale, which has all the properties of an interval scale and has a true zero point (Darminto, 2015). The research data are presented in table 1 below.

Table 1. The results of the 2020 Professional Competency Test

\begin{tabular}{lccc}
\hline & Test I & Test II & Test III \\
\hline Average & 67,03 & 69,66 & 68,35 \\
Highest Score & 85 & 88 & 86,5 \\
Lowest Score & 40 & 48 & 44 \\
Standard Deviation & 11,42 & 9,65 & 10,54 \\
\hline
\end{tabular}

Based on the background described above, a question appears: "will online learning affect the academic achievement of students in elementary, middle school, and college students?" Therefore, concerning this research problem, the researcher proposes a research hypothesis about the value of professional competence achieved by mathematics education students in 2020, which was carried out during the Covid-19 pandemic online with the professional competency values achieved by mathematics education students in 2018 (a long time before the pandemic) conducted face-to-face. Based on research data, the average competency score of students in 2018 was 68.74, while the average competency score of students in 2020 was 68.35. Mathematically, there is a fairly small decrease in value, namely 0.39. Although mathematically, there are differences in values, statistically the decrease of 0.39 is significant or not? This is what needs to be answered. In this connection, the researcher proposes the following hypothesis: 
$H_{0}: \mu \geq 68,74$ (The average professional competency score of students during the Covid-19 pandemic is equal to or higher than the competency score of students before the Covid-19 pandemic)

$H_{1}: \mu<68,74$ (The average professional competency score of students during the Covid-19 pandemic is lower than the competency score of students before the Covid-19 pandemic)

The hypothesis is then tested with an average test of one sample. Next, the t value obtained is calculated $t_{\text {count }}=\frac{68,35-68,74}{\frac{10,54}{\sqrt{30}}}=\frac{-03,39}{1,923}=-0,2027$. Based on the table, it is obtained $t_{(\alpha, \vartheta)}=t_{(0,05,29)}=1,6991$. Therefore, $t_{\text {count }}=-0,2027<t_{(0,05,29)}=1,6991$, and the $t_{\text {count }}$ lies in the critical point. This means that $H_{0}$ was rejected. So the conclusion in this study is that the average score of student professional competence during the Covid-19 pandemic is lower than the competency score of students before the Covid-19 pandemic. It can also be said that online lectures are less effective than face-to-face lectures. This conclusion is in line with Fahrudin's observations which state that distance learning is currently considered ineffective and maximally applied to schools because the infrastructure is inadequate. In addition, he also stated that distance learning based on information technology requires a different approach and evaluation. The implementation of distance learning requires special attention, the infrastructure used, adequate internet network, independent learning and self-motivation in order to be able to follow the learning process well (Fahrudin, 2020).

In addition to some of the problems of distance learning that have been described above, it turns out that there are still other problems that affect the success of the online learning process, namely unequal access to the internet network, inadequate provision of devices (mobile phones), high internet costs, uneven mastery. Science and technology among educators and students, the learning process that uses distance learning methods is not ready, and there is a lack of parents' role who still have difficulty in accompanying their children's learning (Fahrudin, 2020).

Related to distance learning, research results of Firman \& Rahman (2020) shows that online learning has limitations, namely that it does not allow lecturers to directly monitor student activities during lectures, so there is no guarantee that students pay attention to lecturers' explanations during distance learning. Students also find it difficult to understand the material presented online because, in certain complex 
materials, students need direct verbal explanations. In addition, communication between lecturers and students is quite limited. In connection with the conclusions described above, the researcher also discusses things that affect the results of these conclusions, namely student mistakes that occur in completing the tests given. In this case, the correct answers from the students used as the sample are an indicator of the current students' professional competence. Based on Table 1 above, from the results of Test I and Test II, it is found that the average score, the highest score and the lowest score all have increased, but the standard deviation has decreased from 11.42 to 9.65 . The decrease in the standard deviation value indicates that Test II's ability shows more homogeneous results than in Test I. This indicates that in Test II, the students' abilities show more and more the same. Then the other results of this study are in terms of student work results. In this aspect, the researcher can conclude a number of things, including: (1) there are student jobs whose names and roll numbers do not match, for example, the name of student A but the roll number belongs to student $\mathrm{B},(2)$ there is a job where the error and the exact location are exactly the same between students with one another, where this is an indicator of student cooperation (3) there are students who experience delays in sending work results to lecturer on the grounds that internet access is not smooth, (4) there are complaints from some students in following online lectures about the availability of fees for purchasing pulses, (5) less smooth internet access in some locations (residences), so that some students have to find locations to attend lectures. The students' mistakes in answering the questions in this study are presented in table 2 below.

Table 2. Analysis of Errors and Percentage of Students' Correct Answers

\begin{tabular}{|c|c|c|c|}
\hline No & Materials/Questions & Errors & $\begin{array}{c}\text { Correct Answers } \\
(\%)\end{array}$ \\
\hline 1 & $\begin{array}{l}\text { Set Theory } \\
\text { a. Number Operations } \\
\text { b. Set of Numbers } \\
\text { c. Absolute Price } \\
\text { d. Equations and Inequalities } \\
\text { with Absolute Prices }\end{array}$ & $\begin{array}{l}\text { The relative error is } \\
\text { very small in set } \\
\text { operations, but quite } \\
\text { high on the inequality } \\
\text { with absolute prices. }\end{array}$ & $90 \%$ \\
\hline 2 & $\begin{array}{l}\text { Relations and Functions } \\
\text { a. Basic Concepts of Relations } \\
\text { and Functions } \\
\text { b. Various Relationships and } \\
\text { Functions }\end{array}$ & $\begin{array}{l}\text { Relatively minor } \\
\text { errors in } \\
\text { understanding the } \\
\text { inverse and } \\
\text { composition of the }\end{array}$ & $75 \%$ \\
\hline
\end{tabular}



c. Inverse Function
function.
d. Composition of Functions
e. Composition Properties
function.

3 Mathematical logic

a. Mathematical Sentences

b. Proportional Calculus

c. The Laws of Mathematical Logic

$4 \quad$ Function Limit
a. Limit of Algebraic Functions
b. Limit of Trig Functions
Relatively minor errors in the application of the laws of mathematical logic. $80 \%$

The error is quite high in understanding the basic concept of $50 \%$

5 Derivative Functions
a. Derivative Algebra Functions
b. Derivative Trig Functions
c. Maximum and Minimum

$$
\text { limit function. }
$$

The error is sufficient relative to the maximum-minimum use to solve the story $60 \%$ problem.

6 Integral
a. Specific Integral
b. Integral app to calculate area, volume and length of curves

The error is high enough in applying integrals to calculate the area, volume and

Based on table 2 above, the largest percentage of correct answers to the competence test questions that students must complete is set theory material, while the smallest percentage is the limit function material. In general, students can solve problems about set operations because they may have acquired an understanding of this material since middle school. The error that occurs in this set theory's material lies in determining the set of inequality solutions with an absolute value. In this case, students are less careful in applying the properties of inequalities. In general, there are three main characteristics of an inequality that need to be considered, namely: (1) if the two sides of an inequality are added or subtracted by the same number, then the sign of the inequality is constant, (2) if the two sides of an inequality are multiplied or divided by the same positive number and non-zero, then the sign of the inequality is constant, and (3) if the two sides of an inequality are multiplied or divided by the same negative number and not zero, then the inequality sign is the opposite. In addition to the characteristics of these inequalities, the mistakes of students in this subject lie in the inaccuracy in applying the 
properties of absolute prices. The basic concept of the meaning of $|x|$, and some basic properties of $|x|>a ;|x|<b$; and their kinds, must be understood seriously by students. Furthermore, some important characteristics that students need to pay attention to regarding the use of absolute values for linear inequalities are that for every real number x and y apply: (1) $-|\mathrm{x}| \leq \mathrm{x} \leq|\mathrm{x}|$; (2) $|\mathrm{x} . \mathrm{y}|=|\mathrm{x}| \cdot|\mathrm{y}|$; (3) $|\mathrm{x}|-|\mathrm{y}| \leq|\mathrm{x}+\mathrm{y}|$; (4) $|\mathrm{x}+\mathrm{y}| \leq$ $|x|+|y|$; dan (5) $|x-y| \leq|x|+|y|$. Then another error that occurs in the subject of this inequality is modeling to solve story problems. As an example of the mistakes that occur in the following story problems: " $A$ wire with a length of $6 \mathrm{~m}$ will be made a right triangle with a length of $2 \mathrm{~m}$ on the hypotenuse. Determine the boundaries of the size of the base of the right triangle so that the area of the triangle is more than $1.5 \mathrm{~m} 2$ !"

This is a simple story question, but most students have not been able to solve it perfectly. The important thing before solving this problem is to make the modeling of the story problem into a form of inaccuracy. To help make it easier to make mathematical modeling, the story problems need to be drawn according to what is known in the problem. Through the figure as presented below, we will find the inequality model $L=\frac{x \cdot(6-2-x)}{2}=\frac{x \cdot(4-x)}{2}=\frac{4 x-x^{2}}{2} . \mathrm{L}=(\mathrm{x} .(6-2-\mathrm{x})) / 2=(\mathrm{x} .(4-\mathrm{x})) / 2=$ $\left(4 x-x^{\wedge} 2\right) / 2$. Since it is required that $L>1.5$, the solution must be found. The process of completing this is what students have not finished yet.

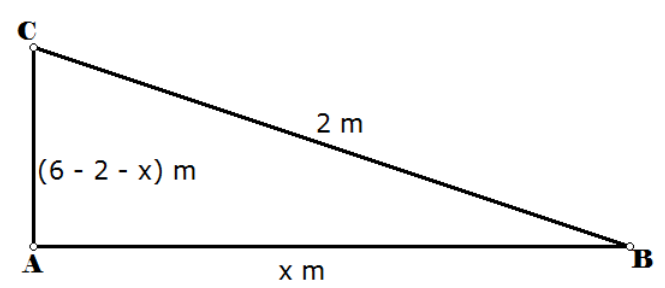

Figure 1. Right Triangle for Modeling

In the subject of limit functions, errors that occur are generally caused by a lack of understanding of the formal definition of the limit function, namely $\lim _{x \rightarrow a} f(x)=L$ which means that for each $\varepsilon>0$ there is $\delta>0$ therefore $0<|x-a|<\delta$ is $|f(x)-L|<\varepsilon$. Because the understanding of this formal definition is not well understood, relational understanding in other concepts is also lacking, for example, the meaning $\delta>0$ so that $|x-a|<\delta$, will have meaning $a-\delta<x<a+\delta$ and $x \neq a$. Because the understanding of these two concepts is still lacking, the implementation in solving limit function 
problems is also lacking. For example, in proving the form $\lim _{x \rightarrow 4}(3 x-10)=2$. Based on the formal definition, things that must be considered in proving the problem are: (1) what is known, namely for each $\varepsilon>0$, (2) what to look for / choose, namely $\delta>0$, and (3) with $|x-4|<\delta$ at the end should indicate that $|f(x)-4|<\varepsilon$ (Darminto, 2015). Based on the foregoing, the biggest mistakes students make in completing the limit function material lies in 3 main things, namely: (1) understanding the concept or definition / formal definition of function limit at a certain point (Suli et al., 2019), (2) understanding relational in the limit function, and (3) understanding in implementing the formal definition/proof of the limit function based on the formal definition. The results of this study are in line with Bahar, et al., Which states that the weaknesses of students in solving the limit function problem lie in the three things above (Bahar et al., 2012). In addition, the error that occurs in solving the limit function problem is breaking the algebraic form into several factors in the limit problem of the algebraic function, for example $\lim _{n \rightarrow 2} \frac{x^{2}-5 x+6}{x^{2}-4}$ becomes $\lim _{n \rightarrow 2} \frac{(x-2)(x-3)}{(x-2)(x+2)}$. Among students who decompose $x^{2}-$ $5 x+6$ into the form $(x-2)(x-3)$ they still have a little difficulty, even though this method of decomposition has been taught since junior high school. When the numerator and denominator have all been broken down, then the same factor can be eliminated so that the solution can be found (in this case $\lim _{n \rightarrow 2} \frac{x^{2}-5 x+6}{x^{2}-4}=-\frac{1}{4}$ ). Even though there are many mistakes in the three things mentioned above, to solve the limit function problem based on the function graph approach, it turns out that students can do it quite well. For example, when students work on the $\lim _{n \rightarrow 2} \frac{x^{2}-5 x+6}{x^{2}-4}$, hen with the graphical approach of the function as shown below, it turns out that they can solve the problem well.

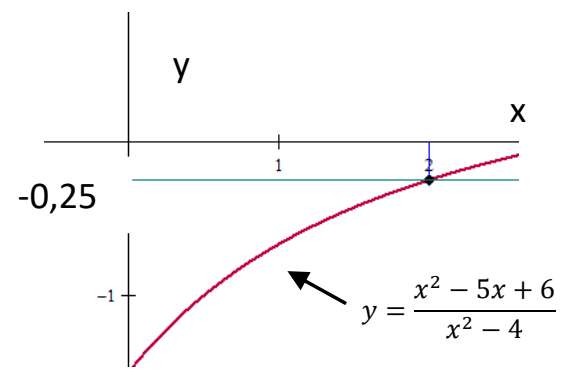

Figure 2. Graph of $\lim _{n \rightarrow 2} \frac{x^{2}-5 x+6}{x^{2}-4}=-0,25$

In addition to student errors in solving the problems above, there are still more mistakes that often occur in solving the limit of the trigonometric function. The results 
showed that the error that occurred, in this case, was changing the form of the problem to a simpler form of the limit function. In this case, the understanding of the identity of the trigonometric function needs to be deepened. For example, the problem $\lim _{x \rightarrow 0} \frac{1-\cos 4 x}{x \sin x}$. If $x=0$ is substituted into the problem, it will be the indefinite form $\frac{0}{0}$. One of the main ideas for solving this problem is to change the form for $\cos 4 x$ to the form (1$\left.2 \sin ^{2} 2 x\right) \mathrm{k}$ because the denominator has the $\sin x$. The process of converting from $\cos 4 x$ to the form $\left(1-2 \sin ^{2} 2 x\right)$ is what is rather difficult for students to do. The identity of the form $\cos 4 x=\cos (2 x+2 x)=\cos 2 x \cos 2 x-\sin 2 x \sin 2 x=$ $\cos ^{2} 2 x-\sin ^{2} 2 x=1-\sin ^{2} 2 x-\sin ^{2} 2 x=1-2 \sin ^{2} 2 x$. Thus the formlim $\lim _{x \rightarrow 0} \frac{1-\cos 4 x}{x \sin x}=$ $\lim _{x \rightarrow 0} \frac{1-\left(1-2 \sin ^{2} 2 x\right)}{x \sin x}=\lim _{x \rightarrow 0} \frac{2 \sin ^{2} 2 x}{x \sin x}=\lim _{x \rightarrow 0} \frac{2 \sin 2 x \sin 2 x}{x \sin x}$.

Then the form $\lim _{x \rightarrow 0} \frac{2 \sin 2 x \sin 2 x}{x \sin x}=\lim _{x \rightarrow 0} 2 \cdot \frac{\sin 2 x}{x} \cdot \frac{\sin 2 x}{\sin x}=2.2 .2=8$.

Student mistakes that occur on the subject of integrals are the application of integrals to calculate area and volume. In calculating the area, the error that occurs is calculating the area for a function with absolute value, for example, simply calculating $\int_{-5}^{5}|x| d x$. From the results of the examination, approximately $50 \%$ of students solve wrong with their answer $\int_{-5}^{5}|x| d x=0$ because $\int_{-5}^{5}|x| d x=\left.\frac{1}{2} x^{2}\right|_{-5} ^{5}=0$. They may forget that $|x|=+x$, where $x \geq 0$ dan $|x|=-x$, where $x<0$. Thus, when $\int_{-5}^{5}|x| d x$ is presented in the form of a picture, the results are as shown in Figure 3 below.

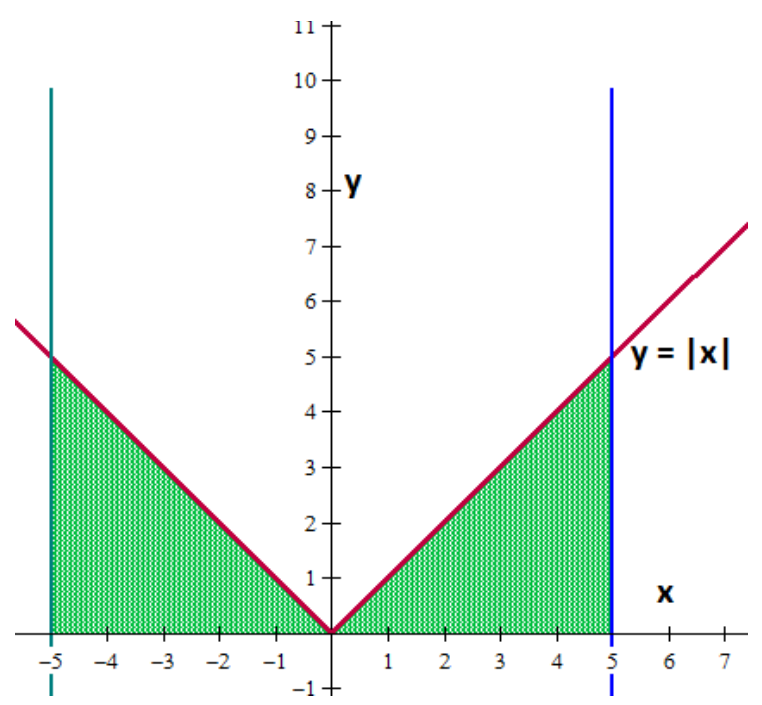


Figure 3. Area $\int_{-5}^{5}|x| d x$.

The correct solution for the above problem is $\int_{-5}^{5}|x| d x=\int_{-5}^{0}-x d x+\int_{0}^{5} x d x=$ $-\left.\frac{1}{2} x^{2}\right|_{-5} ^{0}+\left.\frac{1}{2} x^{2}\right|_{0} ^{5}=12,5+12,5=25$ unit area.

The discussion of student errors in solving problems for the subject of derivative functions lies in deriving a function through a formal definition of the derivative of a function. This error is in accordance with research conducted by Wulandari in which students do not understand the basic concept of derivatives (Wulandari, 2016). As for deriving a function using the formulas that have been taught, most students can complete it well. By definition, if the function $\mathrm{y}=f(x)$, is known, then the derivative of the function $f(x)$ at $x$ is given by $f^{\prime}(x)=\frac{d y}{d x}=\lim _{\Delta x \rightarrow 0} \frac{f(x+\Delta x)-f(x)}{\Delta x}$. In this study, about $40 \%$ of students had difficulty solving derivative questions using this formal definition. They claim that it is too long and complicated, requires high accuracy, and states that it is simpler to use derivative formulas. Another difficulty that students have in completing this derivative subject is the application of derivatives associated with story problems. Solving this problem is actually not difficult, but because it is related to the concept of extreme prices (that is maximum and minimum), more complex thinking is needed. As an example of the story problem below.

"A square sheet of cardboard with a side of $30 \mathrm{~cm}$ will be made a box without a lid by cutting a rectangle in each corner of the cardboard. How many cm of cardboard must be cut so that the box is made to have the maximum volume?

As with the previous story problems, it needs a mathematical equation in the form of modeling of the problem in question. Then, to ease forming the mathematical equation, it is necessary to draw a picture as presented below.

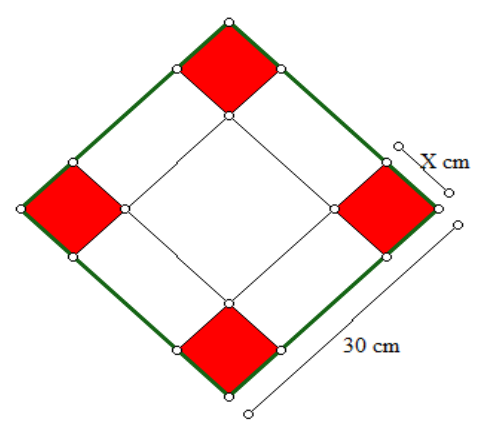

Figure 4. Squared Cartons

Based on Figure 4, it is obtained that the height of the box is $x \mathrm{~cm}$ and the length of the box is $(30-2 x) \mathrm{cm}$. Thus, the mathematical equation model $\mathrm{V}=\mathrm{L}_{\text {pedestal }} \times$ height $=$ 
$(30-2 x)^{2} x=\left(900-120 x+4 x^{2}\right) x=900 x-120 x^{2}+4 x^{3}$ will be obtained. So the mathematical function or equation is $\mathrm{V}=900 x-120 x^{2}+4 x^{3}$. Furthermore, the conditions that must be met in order for the box to have a maximum volume are $\frac{d V}{d x}=0$. From the result of this reduction, the value of $x$ (in this case $x=5$ ) will definitely be obtained so that the maximum volume of the box can be found. The basic concept in modeling is what many students know, so they have difficulty solving these problems.

The error that occurs in working on the subject matter of the function lies in the process of finding the inverse of a function. For example, the problem in this study is to determine a function $f$, if the function $g$ and $(f \circ g)$ are known. If $g(x)=3 x+2$ and $(f \circ$ $g)(x)=18 x^{2}+39 x+22$, find $f(x)$ ! In solving this problem, generally the students were correct in the initial step, namely finding $(f \circ g)(x)=18 x^{2}+39 x+22 \Leftrightarrow f(g(x))=18 x^{2}$ $+39 x+22$. Selanjutnya pada langkah berikutnya yaitu $f(3 x+2)=18 x^{2}+39 x+22=$ $2(3 x+2)^{2}-(\ldots \ldots .)+.39 x+22$, they have a little trouble finding the algebraic form in parentheses. This stage is very important in solving the inverse problem. This is a problem solving strategy by prioritizing the process aspect and the steps in solving a mathematical problem (Fatmawati, et all., 2014: 914). Therefore, some students ultimately failed to solve the problem. In fact, if they want to calculate the value of the function $f(3 x+2)$ by following the rule $(f \circ g)(x)$, then they will definitely find the algebraic form in question (in this case it is $(24 x+8)$ so that we get $f(3 x+2)=2(3 x+$ $2)^{2}-24 x-8+39 x+22$. Next, the solution step becomes $f(3 x+2)=2(3 x+2)^{2}+15 x+14$ $\Leftrightarrow f(3 x+2)=2(3 x+2)^{2}+5(3 x+2)+4$, so you get the final result $f(x)=2 x^{2}+5 x+4$.

The mistake of most students in working on problems on the subject of mathematical logic is proving a proposition. In mathematical logic, the method of proving a proposition can be done in two ways, namely (1) the method of proving with a truth table, and (2) the method of proof using the laws of mathematical logic. In this study, students generally can solve problems using truth tables. This is easy to do because they have been introduced to the truth table of conjunctions, disjunctions, implications, and bi-implications since middle school. Then, the method of proof with the laws of mathematical logic can be done in two ways, namely direct or indirect proof. The difficulty of students in proving this second method is due to the difficulty of selecting and applying the right law to solve problems about mathematical logic. 


\section{CONCLUSION}

Based on the hypothesis testing and discussion above, this research concluded that the average professional competency score of students whose lectures were conducted online during the Covid-19 pandemic was lower than the professional competency scores of students whose lectures were conducted face-to-face or offline. The decline in professional competence score was influenced by a number of factors, including unequal network access, inadequate internet network, poor information technology, and low learning independence from students. As a result of several deficiencies in online learning during the Covid-19 pandemic, students have not fully understood some of the basic concepts and understanding of a particular subject. This caused a decline in the students' professional competence score.

\section{REFERENCES}

Ambarawati, M., Mardiyana., \& Subanti, S. (2014). Profil Proses Berpikir Kritis Siswa Kelas VIII SMP Negeri 3 Surakarta dalam Memecahkan Masalah Pokok Bahasan Sistem Persamaan Linear Dua Variabel (SPLDV) ditinjau dari Kecerdasan Majemuk dan Gender. Jurnal Elektronik Pembelajaran Matematika, 2(9).

Arifin, Z. (2017). Mengembangkan Instrumen Pengukuran Critical Thinking Skills Siswa pada Pembelajaran Matematika Abad 21. Jurnal Theorems (The Original Research of Mathematics), 1(2).

Bahar, E. E., Rahman, A., \& Minggi, I. (2012). Analisis Pemahaman Mahasiswa Terhadap Konsep Limit Fungsi di Satu Titik (Studi Kasus pada Mahasiswa Jurusan Matematika FMIPA UNM). Sainsmat, 1(2), 181-190.

Darlin. (2020). Pengaruh Persepsi Siswa terhadap Kompetensi Profesional Guru, Perhatian Orang Tua, dan Pemanfaatan Waktu Belajar di Rumah dengan Hasil Belajar Matematika Siswa Kelas XI IPS SMAN 1 Kusambi. Gema Kampus, 15(1), 41-49. https://e-journal.iyb.ac.id/index.php/gemakampus/article/view/101/93

Darminto, B. P. (2015). Matematika I. UMP.

Darminto, B. P. (2018). Mengukur Kompetensi Profesional Mahasiswa Pendidikan Matematika Universitas Muhammadiyah Purworejo. UMP.

Daryati, N. (2016). Pengaruh Kompetensi Profesional dan Motivasi Berprestasi Siswa Terhadap Hasil Belajar Matematika. Jurnal Penelitian Pendidikan Dan Penilaian Pendidikan, 1(1), 123-137. https://doi.org/10.22236/JPPP 
Duron, R., Limbach, B., \& Waugh, W. (2006). Critical Thinking Framework For Any Discipline. International Journal of Teaching and Learning in Higher Education, 17(2). https://www.isetl.org/ijtlhe/pdf/IJTLHE17(2).pdf\#page=89

Fahrudin, A. R. (2020). Permasalahan dan Solusi Pembelajaran Jarak Jauh di Masa Pandemi Covid-19. Samarinda Pos. https://sapos.co.id/2020/11/29/ perma-salahandan-solusi-pembelajaran-jarak-jauh-di-masa-pandemi-covid-19/

Firman, \& Rahman, S. R. (2020). Pembelajaran Online di Tengah Pandemi Covid-19. Indonesian Journal of Educational Science (IJES), 2(2).

Girsang, E. (2020). 5 Kendala Utama yang Dihadapi Siswa Selama Belajar Daring di Masa Pandemi. https://www.edoo.id/2020/08/29/5-kendala-utama-yang-dihadapisiswa-selama-belajar-daring-di-masa-pandemi/

Karim, \& Normaya. (2015). Kemampuan Berpikir Kritis Siswa dalam Pembelajaran Matematika dengan Menggunakan Model Jucama di Sekolah Menengah Pertama. Jurnal Pendidikan Matematika, 3(1).

Law No. 14 of 2005, Pub. L. No.14 of 2005.

Maulana. (2017). Konsep Dasar Matematika dan Pengembangan Kemampuan Berpikir Kritis - Kreatif. UPI Sumedang Press.

Suli, M., Tahmir, S., \& Side, S. (2019). Description on Errors in Proving Function Limit of Students in Mathematics Education in Universitas Negeri Makassar [UNM]. http://eprints.unm.ac.id/12995/1/Artikel Misdalifah Suli 162050701060.pdf

Sumargiyani, \& Nafi'ah, B. (2020). Analysis of the Mathematical Communication Ability of Pre-Service Mathematics Teachers through Online Learning during the Covid-19 Pandemic. Hipotenusa: Journal of Mathematical Society, 2(2).

Wahyudi. (2010). Standar Kompetensi Profesional Guru. Jurnal Pendidikan Sosiologi Dan Humaniora, 1(2), 107-119. https://doi.org/http://dx.doi.org/10.26418/jpsh.v1i2.385

Wahyuni, S. (2017). Development Test System Based On Linear Equations Two Variable Revised Taxonomy Bloom to Measure High Order Thinking Skill at Student Class VIII SMPN Sungguminasa Gowa. Jurnal Daya Matematis, 5(1).

Wulandari, N. B. (2016). ANALISIS KESALAHAN MAHASISWA DALAM PENYELESAIAN MASALAH TURUNAN [UMS]. 
Hipotenusa Journal, 3 (1), June 2021

Bambang Priyo Darminto, Budy Sugandi

http://eprints.ums.ac.id/44937/1/ARTIKEL PUBLIKASI.pdf

Zein, M., \& Ariyani, L. (2017). Analisis Pengaruh Bimbingan Orang Tua terhadap Prestasi Akademik Mahasiswa. Jurnal Humaniora Teknologi, 3(1). 